\title{
The Right to Life Under the EU Charter and Cooperation with Third States to Combat Human Smuggling
}

\author{
Vladislava Stoyanova*
}

(Received 23 February 2020; accepted 03 March 2020)

\begin{abstract}
According to EU policy documents, "[s]aving lives of people in distress is a primary goal of EU action in relation to managing the EU external borders." The EU preferred strategy to achieve this objective is to take measures against human smuggling - including the establishment of cooperation with third countriesostensibly so that migrants are contained and their irregular movement is prevented. This Article examines whether this strategy complies with the positive obligations corresponding to the right to life as enshrined in Article 2 of the EU Charter of Fundamental Rights. After considering any formal obstacles that might prevent the activation of the Charter, this Article clarifies the factors that determine the scope of these positive obligations. Procedural and substantive obligations are then distinguished. The procedural positive obligation demands that the EU and its Member States (MS) consider alternatives to the measures of containment. Due to difficulties in assessing the reasonableness of such alternatives, the EU and the MS are also under the positive obligation to initiate studies that can provide reliable evidence that alternative measures - such as the possibility of issuing humanitarian visas-would be too burdensome. As to the substantive positive obligation corresponding to the right to life, this Article will argue that the EU and the MS need to be attentive about the cumulative outcome of their migration policies. The more successful they are in their indiscriminate containment policies-and the more unlikely any protection possibilities in the region of containment-the more likely it is that the positive obligation to protect life will remain unfulfilled.
\end{abstract}

Keywords: Human smuggling; the right to life; EU Charter; positive human rights obligations

\section{A. Introduction}

The external dimension of EU migration policy implies the development and consolidation of cooperation with third countries so that migrants are contained and their irregular movement is prevented. ${ }^{1}$ A priority within this dimension has been the undertaking of more effective measures against human smuggling ${ }^{2}$ as a means of irregular travel to and entry into the EU. In the

\footnotetext{
${ }^{*}$ Associate Professor, Faculty of Law, Lund University. This Article was first presented at a workshop on "Accountability for Human Rights Violations in Migration Control” held in Oxford on Nov. 10, 2018, that was funded by an ERC Starter Grant RefMig (Grant Agreement 716968), of which Cathryn Costello is the PI.

${ }^{1}$ Eur. Parl., EU Cooperation with Third Countries in the Field of Migration. Study for the LIBE Committee, at 15, http://www. europarl.europa.eu/RegData/etudes/STUD/2015/536469/IPOL_STU\%282015\%29536469_EN.pdf (2015); A European Agenda on Migration, COM (2015) 240 final (May 13, 2015); Progress Report on the Implementation of the European Agenda on Migration, COM (2019) 481 final (Oct. 16, 2019).

${ }^{2}$ See Conclusions from the European Council Meeting, at para 5, EUCO 9/18 (June 2018); Malta Declaration by the Members of the European Council on the External Aspects of Migration: Addressing the Central Mediterranean Route, at paras. 3, 5, http://www.consilium.europa.eu/en/press/press-releases/2017/02/03/malta-declaration/.
}

(C) The Author(s) 2020. Published by Cambridge University Press on behalf of the German Law Journal. This is an Open Access article, distributed under the terms of the Creative Commons Attribution licence (http://creativecommons.org/licenses/by/4.0/), which permits unrestricted re-use, distribution, and reproduction in any medium, provided the original work is properly cited. 
absence of legal channels for asylum-seekers to travel to countries of destination, human smuggling provides a means to access EU territory. The services offered by smugglers in terms of facilitation of movement and irregular border crossings - some of which might involve exploitative arrangements amounting to human trafficking ${ }^{3}$ - meet this demand. ${ }^{4}$

Given that human smuggling can lead to serious suffering and even death, ${ }^{5}$ measures aimed to prevent it appear justifiable. Nonetheless, could these very measures at the same time also constitute human rights law violations? Might the EU and the Member States (MS) violate human rights law with the anti-smuggling measures that form part of the "external dimension" of the EU migration policy? These questions have been examined from the perspective of the right to asylum and the prohibition on non-refoulement. In particular, scholars have examined the compatibility of the measures within the "external dimension" of the EU migration policy with these two rights. ${ }^{6}$ This Article, however, offers a new perspective because it engages with the right to life, which is a right generally considered to be of fundamental importance, and highly relevant given the massive loss of life in the context of irregular migration. This Article also focuses specifically on the antismuggling measures. As opposed to other measures of externalized border control—such as visa requirements and carrier sanctions-the anti-smuggling measures have been persistently framed by the EU as necessary to save lives. ${ }^{7}$ Doing so creates a complex situation where certain objectives and measures, notably saving lives versus border control through containment, might potentially be in conflict. In addition, and despite the difficulties surrounding the causal links between the anti-smuggling measures and the dangers to irregular migrants' lives, ${ }^{8}$ connections between the other measures of externalized border control undertaken by countries of destination and risks to life are perhaps too remote to support a meaningful assessment in relation to the right to life. Finally, the maritime environment in which the anti-smuggling measures are usually undertaken also adds distinctiveness because of inherent dangers within this environment.

The right to life in the context of migration control has attracted relatively little academic attention. The scholarship of Thomas Spijkerboer is a prominent exception in this respect. ${ }^{9}$

\footnotetext{
${ }^{3} \mathrm{~A}$ person can become a victim of human trafficking even if the individual crosses international borders regularly. Human smuggling necessarily implies irregular border crossing. See Vladislava Stoyanova, Human TrafFicking and Slavery Reconsidered. Conceptual Limits and States' Positive Obligations in European Law 32 (2017).

${ }^{4}$ For one of the first sources on this issue, see John Morrison \& Beth Crosland, The Trafficking and Smuggling of Refugees: The End Game in European Asylum Policy? (New Issues in Refugee Res., Working Paper No. 39, 2001). See also Nina Perkowski \& Vicki Squire, The Anti-Policy of European Anti-smuggling as a Site of Contestation in the Mediterranean Migration "Crisis," 45 J. ETHNIC \& MigRation STUD. 2167 (2019). For the conceptualization of human smuggling as "the result of man-made structures of social control," see TheOdore Baird, Human SMuggling In The EASTERN MEDITERRANEAN 3 (2017).

${ }^{5}$ For a collection of official evidence, see Deaths at the Border of Southern Europe, Human COSTS OF BORDER CONTROL (2015), http://www.borderdeaths.org/.

${ }^{6}$ Thomas Gammeltoft-Hansen \& James Hathaway, Non-Refoulement in a World of Cooperative Deterrence, 53 CoLUM. J. Transnat'L L. 235 (2015); Bill Frelick et al., The Impact of Externalization of Migration Controls on the Rights of Asylum Seekers and Other Migrants, 4 J. Migration \& Hum. Security 190 (2016); MaArten Den Heijer, Europe And Extraterritorial Asylum (2012); Extraterritorial Immigration Control: Legal Challenges (Bernard Ryan \& Valsamis Mitsilegas eds., 2010); Thomas Gammeltoft-Hansen, Access to Asylum: International Refugee LaW and the Globalisation of Migration Control (2011); Violeta Moreno-LaX, Accessing Asylum in Europe: Extraterritorial Border Control and Refugee Rights Under EU LaW (2017).

${ }^{7}$ Progress Report on the Implementation of the European Agenda on Migration, at 12, COM (2019) 126 final (Mar. 6, 2019). I do not challenge the assertion that the EU and the MS genuinely have the objective to save lives. For such challenges, including the characterization of the assertion as "hypocrisy," see Eugenio Cusumano, Migrant Rescue as Organized Hypocrisy: EU Maritime Missions Offshore Libya Between Humanitarianism and Border Control, 54 COOPERATION \& CONFLICT 3 (2019).

${ }^{8}$ See Sections D.I and D.II below.

${ }^{9}$ Thomas Spijkerboer, Wasted Lives: Borders and the Right to Life of People Crossing Them, 86 NORDIC J. INT'L L. 1 (2017) [hereinafter Spijkerboer 1]. See also Thomas Spijkerboer, Are European States Accountable for Border Deaths?, in THE AsHGATE Research Companion To Migration Law (Satvinder Juss, ed. 2013) [hereinafter Spijkerboer 2]; Thomas Spijkerboer, Human Costs of Border Control, 9 EUR. J. Migration \& L. 127-39 (2007) [hereinafter Spijkerboer 3]; Thomas Spijkerboer, Moving Migrants, States and Rights: Human Rights and Border Deaths, 7 L. \& ETHICs Hum. RTs. 213 (2013).
} 
He has argued that "states have assumed far-reaching positive obligation to protect the right to life of regular travelers, but recognize only very limited obligations vis-à-vis irregularized travelers." 10 He has compared relevant regulations aimed at safeguarding life in the field of aviation law, maritime law, and the law on migrant smuggling. ${ }^{11}$ This comparison led to the conclusion that protecting life is only a secondary aim of the UN Protocol against Smuggling of Migrants by Land, Sea and Air (the UN Smuggling Protocol), ${ }^{12}$ with the primary aim being combatting crime and border control. ${ }^{13}$ This secondary aim-protection of life-is pursued in two main ways: Through prohibitions, such as criminalization of human smuggling, and through search and rescue that is initiated at a point in time when the risk to life has already materialized. ${ }^{14}$ As Spijkerboer has rightly observed, these measures might be inadequate for destination states to fulfill their positive obligations to safeguard the right to life under the European Convention on Human Rights (ECHR). ${ }^{15}$ While in this Article I also invoke positive obligations, my contribution lies in the detailed discussion of the complex analytical issues as to the activation of these obligations and their scope. An additional distinctive feature of this Article is that it engages with positive obligations corresponding to the right to life not under the ECHR, but under the EU Charter of Fundamental Rights. ${ }^{16}$ As opposed to the ECHR, the Charter does not contain a jurisdictional clause and, pursuant to Article 52(3), it can provide protection that is more extensive than the ECHR. The triggering of the Charter in relation to measures with extraterritorial effects - and the compatibility of these measures with positive human rights obligations - are issues yet to be fully explored. In addressing them, I suggest that the extraterritorial effects of the EU border control policies and the involvement of third parties - smugglers and third countries - might not hinder the imposition of obligations upon the EU and the MS under EU fundamental rights law.

The question at the core of this Article can be formulated in the following way: In the context of cooperation with third countries to prevent human smuggling, to what extent do the EU and the MS comply with their positive obligations corresponding to the right to life under the Charter? ${ }^{17}$ To answer this question, the characteristics of the anti-smuggling measures that form part of the external dimension of the EU migration policy will be clarified in Part B. The following characteristics are distinguished: Extraterritoriality, involvement of many actors, and informality - the challenges of each from the perspective of human rights law are explained and addressed. Part $\mathrm{C}$ argues that Article 2 of the Charter triggers positive obligations. The factors that determine the scope of these obligations-knowledge, causation, and reasonableness - are introduced by drawing on the ECtHR case law. With reference to these three factors, Part D analyzes whether the EU and the MS fulfill their positive obligations corresponding to the right to life in the context of the anti-smuggling measures. Two types of positive obligations are distinguished: A procedural one and a substantive one. The procedural positive obligation demands that the EU and the MS consider alternatives to the measures of containment. Because the reasonableness of such

\footnotetext{
${ }^{10}$ See Spijkerboer 1, supra note 9, at 4.

${ }^{11}$ Protocol against the Smuggling of Migrants by Land, Sea and Air, supplementing the United Nations Convention against Transnational Organized Crime, Jan. 28, 2004, 2241 U.N.T.S. 480 [hereinafter the UN Smuggling Protocol].

${ }^{12} I d$.

${ }^{13} I d$. at 17 .

${ }^{14} I d$. at 13 .

${ }^{15}$ See Spijkerboer 2, supra note 9, at 213.

${ }^{16}$ Charter of Fundamental Rights of the European Union, 2016 O.J. (C 202) 389.

${ }^{17}$ This Article does not address procedural issues-how legal responsibility for failure to fulfill positive obligations could be established before courts given the existing procedural avenues. Admittedly, the Court of Justice has limited competence over the Common Foreign and Security Policy, which might preclude it from assessing whether measures taken within this policy field are compatible with the EU Charter. See Graham Butler, Legal Responses to the European Union's Migration Crisis, 19 SAn Diego InT'L L.J. 277, 290 (2018). For further discussion of procedural difficulties, see Melanie Fink, FronteX AND Human Rights: Responsibility in ‘Multi-Actor Situations’ under the ECHR and EU Public Liability Law 8 (2018).
} 
alternatives might be difficult to assess, the EU and the MS are under the positive obligation to undertake empirical studies to provide reliable evidence that alternative measures-for example, the possibility for issuing humanitarian visas-would be potentially too burdensome and unreasonable. As to the substantive positive obligation corresponding to the right to life, I explain how its vagueness makes it difficult to formulate concrete measures demanded by the obligation. Yet, given that the anti-smuggling measures do not differentiate between persons in need of protection and other categories of migrants, rather indiscriminately containing all, I argue that the positive obligation corresponding to the right to life compels the EU and the MS to be attentive to the cumulative outcome of their migration policies. The more successful they are in their containment policies, and the more unlikely any protection possibilities in the region of containment are, the more likely it is that the positive obligation to protect life will remain unfulfilled.

\section{B. Anti-Smuggling as a Priority in the Cooperation with Third States}

Since 2016, the EU and the MS have started to more intensively apply forms of migration control that are based on contacts with third countries, ${ }^{18}$ specifically, by enlisting the latter to apply exit and departure controls. ${ }^{19}$ These controls have been part of the external dimension of the EU migration policy, ${ }^{20}$ which has taken various forms: Assisting third countries to apply stricter border controls, ${ }^{21}$ including pull-backs of migrants; ${ }^{22}$ supporting and training, for example, of the Libyan coast guards and navy; ${ }^{23}$ and providing border control equipment and intelligence. ${ }^{24}$ The demand that third countries contain movement normally comes as part of a larger package of financial forms of assistance and other incentives. ${ }^{25}$

In EU policy documents, the primary objective of these external controls is framed as saving lives and preventing migrants' embarkation on hazardous journeys. The measures are thus presented as addressing humanitarian concerns. ${ }^{26}$ These humanitarian objectives are also framed as combating

\footnotetext{
${ }^{18}$ Such policies have been applied before; however, they have become particularly prominent since 2016. Paula Garcia Andrade, EU External Competences in the Field of Migration: How to Act Externally When Thinking Internally, 55 Common MkT. L. Rev. 157, 157-58 (2018). For a historical overview, see Andrew Wolman, The Role of Departure States in Combating Irregular Emigration in International Law: A Historical Perspective, 31 INT'L J. RefugEe L. 30 (2019).

${ }^{19}$ Establishing a New Partnership Framework with Third Countries, at 7, COM (2016) 385 final (June 7, 2016).

${ }^{20}$ Malta Declaration by the Members of the European Council on the External Aspects of Migration: Addressing the Central Mediterranean Route (Feb. 3, 2017), https://www.consilium.europa.eu/en/press/press-releases/2017/02/03/malta-declaration/.

${ }^{21}$ Progress Report on the Partnership Framework with Third Countries, at 6, COM (2017) 471 final (Sept. 6, 2017).

${ }^{22}$ Nora Markard, The Right to Leave by Sea: Legal Limits on EU Migration Control by Third Countries, 27 EUR. J. INT'L L. 591 (2016).

${ }^{23}$ Progress Report on the European Agenda on Migration, at 8, COM (2017) 669 final (Nov. 15, 2017); Communication on Establishing a New Partnership Framework with Third Countries, at 15, COM (2016) 385 final (Jul. 6, 2016). On the training in Libya, see Operation SOPHIA: Package 2 of the Libyan Navy Coast Guard and Libyan Navy Training Launched Today, EUROPEAN UNION: EXTERNAL ACTION SERVICE (Jan. 30, 2017) https:/eeas.europa.eu/headquarters/headquarters-homepage/19518/ operation-sophia-package-2-libyan-navy-coast-guard-and-libyan-navy-training-launched-today_en.

${ }^{24}$ Italy-Libya Memorandum Agreement, available at http://eumigrationlawblog.eu/wp-content/uploads/2017/10/ MEMORANDUM_translation_finalversion.doc.pdf. See Andrea Spagnolo, The Conclusion of Bilateral Agreements and Technical Arrangements for the Management of Migration Flows: An Overview of the Italian Practice, 28 ITALIAN Y.B. INT'L L. 211 (2019).

${ }^{25}$ Nora El Qadim, The Funding Instruments of the EU's Negotiation on External Migration Policy: Incentives for Cooperation, in EU External Migration Policies in an Era of Global Mobilities: Intersecting Policy Universes 341 (Sergio Carrera et al., eds., 2019).

${ }^{26}$ Frelick, supra note 6, at 193; Andrew Geddes \& Luca Lixi, New Actors and New Understanding of European Union External Migration Governance?, in EU External Migration Policies in aN ERA OF Global Mobilities: Intersecting Policy Universes 60, 69 (Sergio Carrera et al., eds., 2019).
} 
human trafficking and human smuggling. ${ }^{27}$ For example, the EU Commission has clarified that a financial contribution of EUR 50 million to Niger "aims at enhancing the state capacities in the sectors of security, counter smuggling, and include addressing trafficking in human beings." 28 Egypt has been supported by the EU "on migration governance and the prevention of irregular migration, trafficking in human beings and smuggling of migrants, as well as in the field of migrants' rights and protection." 29 EUNAVFOR Operation Sophia is also framed as an antismuggling operation, ${ }^{30}$ as well as an operation that aims at "complementary training and capacity building of the Libyan Coast Guard." 31 In its Progress Report on the Partnership Framework with Third Countries under the European Agenda on Migration, the European Commission concluded that "[e]nhancing border control as well as anti-smuggling and migration management capabilities in countries of origin and transit contributes to dismantling smugglers networks, reducing outflows and enhancing security and stability." ${ }^{2}$ The Commission has also explicitly stated that "[t]ackling smuggling is a core part of the Partnership Framework approach." ${ }^{3}$

The practical effect of these restrictions is the containment of people within certain countriessuch as Libya ${ }^{34}$ and Turkey ${ }^{35}$ - where human rights violations are well-documented. Three key factors characterize these cooperation-based measures: Extraterritoriality (Section B.I); involvement of many actors (Section B.II); and informality (Section B.III).

\section{Extraterritoriality}

The cooperation-based measures for combatting human smuggling are executed beyond the borders of the EU. The EU and the MS usually have no direct contact with the people who are affected. As a consequence, these measures have been labeled "contactless control." 36 The absence of contact and the extraterritoriality of the measures raise challenges from the perspective of human rights law. In particular, they raise the question of whether the EU and the MS owe any human rights obligations to individuals who are located beyond their borders and who are not in direct contact with their authorities, but are simply affected by the measures that are part of the EU external policies. ${ }^{37}$

\footnotetext{
${ }^{27}$ See Progress Report on the European Agenda on Migration, at 11, COM (2017) 669 final (Nov. 15, 2017) ("Breaking the business model of smuggling remains a priority."). Commission Contribution to the EU Leaders' Thematic Debate on a Way Forward on the External and the Internal Dimension of Migration Policy, 7 COM (2017) 820 final (Dec. 7, 2017).

${ }^{28}$ Fifth Report on the Partnership Framework with Third Countries under the European Agenda on Migration, at 3, COM (2017) 471 final (Sept. 6, 2017). The cited EU documents systematically conflate human trafficking and human smuggling.

${ }^{29}$ Id. at 9.

${ }^{30}$ Council Decision 2015/778, 2015 O.J. (L 122).

${ }^{31}$ Fifth Report on the Partnership Framework with Third Countries under the European Agenda on Migration, at 12, COM (2017) 471 final (Sept. 6, 2017).

${ }^{32} I d$. at 14 .

${ }^{33}$ See Progress Report on the European Agenda on Migration, at 11, COM (2017) 669 final (Nov. 15, 2017); Commission Contribution to the EU Leader's Thematic Debate on a Way Forward on the External and the Internal Dimension of Migration Policy, 7 COM (2017) 820 final (Dec. 7, 2017).

${ }^{34}$ Libya "remains by far the largest embarkation point and transit country." Addressing the Refugee Crisis in Europe: The Role of EU External Action, at 3, JOIN (2015) 40 final (Sept. 9, 2015); Migration on the Central Mediterranean Route: Managing Flows, Saving Lives, at 2, JOIN (2017) 4 final (Jan. 25, 2017).

${ }^{35}$ See Commission Memorandum MEMO/15/5860, EU-Turkey Joint Action Plan, at Part II (Oct. 15, 2015), https://ec. europa.eu/commission/presscorner/detail/en/MEMO_15_5860. For an analysis of the situation of Syrians in Turkey, see Meltem İneli-Ciğer, Protecting Syrians in Turkey: A Legal Analysis, 29 INT'L J. RefugeE L. 555 (2017).

${ }^{36}$ Mariagiulia Giuffré \& Violeta Moreno-Lax, The Rise of Consensual Containment: From "Contactless Control" to "Contactless Responsibility" for Forced Migration Flows, in Research Handbook on InTernational Refugee Law 82 (Satvinder Juss ed., 2019).

${ }^{37}$ The adoption of these measures—-such as financial support and the provision of equipment and intelligence-is purely domestic conduct, but they affect individuals not located in the EU. See Lorand Bartels, The EU's Human Rights Obligations in Relation to Policies with Extraterritorial Effect, 25 EUR. J. INT'L L. 1071 (2014).
} 
The ECHR might be inapplicable in this case because the individuals affected by the antismuggling measures are not under any territorial or personal control exercised by the $\mathrm{MS}^{38}$ and thus are arguably not within these states' jurisdiction in the sense of Article 1 of the Convention. The EU Charter, in contrast, contains no jurisdictional clause, implying no initial threshold in the form of territorial or person $\operatorname{control}^{39}$ that might condition the applicability of the Charter. ${ }^{40}$ The EU institutions and the MS might thus be bound by the Charter irrespective of where they act, where their decisions might have effect, and where the affected individuals might be located. This possibility would imply that when the EU exercises its powers, "it owns human rights obligations to persons affected by such exercise of power, irrespective of the location of those persons." 41 As Moreno-Lax and Costello have observed, "EU fundamental rights obligations simply track all EU activities." 42 It also needs to be acknowledged, however, that it is difficult to provide conclusive answers as to the extraterritorial reach of the Charter. This is an area where there is still a wide scope of ambiguity, and it would be beyond the reach of this Article to resolve this uncertainty. ${ }^{43}$

Even if the extraterritorial application of the Charter is taken as a starting point, the extraterritorial location of the individuals affected by the anti-smuggling measures - and the absence of physical control over them-are relevant for the substantive analysis regarding the activation and the scope of any positive human rights law obligations. This analysis will be undertaken in Part D. Although I note the insecurity surrounding the application of the Charter rights to EU policy measures with extraterritorial effects, I do not seek to resolve it. Instead, I take the extraterritorial application of the Charter as a point of departure and focus on the difficult and related issues that arise in the substantive analysis of any positive human rights law obligation.

\section{Involvement of Different Actors}

The external dimension of the EU migration policies is characterized by a cooperative framework that involves a multiplicity of actors - the EU, MS, EU agencies, and third countries-whose specific roles might be difficult to unravel. At least two aspects of this complexity need to be distinguished.

The first aspect concerns the overlapping of actions undertaken by the EU and the MS, on the one hand, and the cooperating third states, on the other hand. ${ }^{44}$ Eventually, the external dimension of the EU migration policy — and its ultimate objective to prevent movement towards the EU_cannot be successful without the involvement of third countries. It is, for example, the Libyan border control guards who might intercept people who have boarded a boat destined

\footnotetext{
${ }^{38}$ See generally Samantha Besson, The Extraterritoriality of the European Convention on Human Rights: Why Human Rights Depend on Jurisdiction and What Jurisdiction Amounts to, 25 LEIDEN J. INT'L L. 857 (2012). Creative arguments have been forwarded for interpreting the jurisdictional threshold under Article 1 of the ECHR in a more expansive way so that the application of the EHCR can be triggered. See, e.g., Giuffré \& Moreno-Lax, supra note 36; Miles Jackson, Freeing Soering: The ECHR, State Complicity in Torture, and Jurisdiction, 27 EUR. J. INT'L L. 817 (2016).

${ }^{39} \mathrm{See}$ Al-Skeini and Others v. United Kingdom, App. No. 55721/07, paras. 130-42 (Jul 7, 2011), http://hudoc.echr.coe.int/ eng?i=001-105606.

${ }^{40}$ See Violeta Moreno-Lax \& Cathryn Costello, The Extraterritorial Application of the EU Charter of Fundamental Rights: From Territoriality to Factivity, the Effectiveness Model, in The EU Charter of Fundamental Rights: A Commentary 1658 (Steve Peers et al. eds., 2014).

${ }^{41}$ Cedric Ryngaert, EU Trade Agreements and Human Rights: From Extraterritorial to Territorial Obligations, 20 INT'L Community L. Rev. 374, 380 (2018).

${ }^{42}$ Moreno-Lax \& Costello, supra note 40. See also Antal Berkes, The Extraterritorial Human Rights Obligations of the EU in its External Trade and Investment Policies, 2 Eur. \& WORLD: L. Rev. 1 (2018).

${ }^{43}$ See Bartels, supra note 37, at 1072, 1075 (stating that "it is not certain whether fundamental rights apply to policy measures with extraterritorial effects").

${ }^{44}$ See Jorrit J. Rijpma, External Migration and Asylum Management: Accountability for Executive Action Outside EU-Territory, 2 EUR. PAPERS 571, 587 (2017).
} 
to cross the Mediterranean Sea. It is the authorities of Niger who might confiscate vehicles used for the smuggling of people to Libya. ${ }^{45}$ Although it is ultimately the interests of the EU and the MS that dictate the measures of containment-which necessitates an independent review of these actors' conduct against human rights law standards - the involvement of third states might make it harder to establish causation between the EU's conduct and the MS's conduct, and possible harms, in the form of loss of life or risk to life. I return to this in Part D.

The review of the EU and the MS conduct is further complicated by the unclear division of responsibility and competence in this area between them. This aspect requires some serious engagement, starting with the observation that the EU as an organization has limited competences. This observation implies that it is allowed to take actions legally only if these are within the competences conferred on it by EU Treaties and only if these actions have a legal basis as indicated in the said Treaties. ${ }^{46}$ Migration and asylum policies are part of the Area of Freedom, Security and Justice-a field in which the EU and its MS as a rule have shared competences. ${ }^{47}$

Cooperation-based measures with third countries, however, are not normally adopted based on the EU competence in the Area of Freedom, Security and Justice, but rather on EU external relations competence, of which the EU Common Foreign and Security Policy forms part. Migration control is thus externalized in both the physical sense-the physical location of the control is not even close to the EU territory- "but also in the EU policy making sense as the moves to control migration shift from the internal policy-making sphere to the external, foreign-policy making sphere, where the Council (and hence the MS) remain largely in control." 48 Therefore, the fields of EU external relations law and EU migration law have been merged.

It needs to be clarified that the only external relation competence explicitly transferred to the EU in the migration field is the conclusion of readmission agreements with third countries. ${ }^{49}$ Beyond this point, the Treaties do not provide explicitly that the EU has the competence to act externally in the field of migration. The EU might, however, have implied external competence. ${ }^{50}$ Recourse to this competence would depend on whether external actions by the EU-such as the conclusion of an international agreement by the EU-might facilitate the achievement of the objectives of internal competence transferred to the Union. In the field of migration, it can be relatively easily determined that facilitation takes place. In particular, partnership and cooperation with third countries serve the objective of managing inflows of people into the EU. Overall, Article 216(1) TFEU, which codifies the implied external competence of the EU, allows for wide flexibility as to when the EU is competent to conclude agreements with third countries.

Ultimately, the division of competences between the EU and the MS in the area of the Common Foreign and Security Policy is unclear. ${ }^{51}$ Similarly, the distinction as to whether measures are

\footnotetext{
${ }^{45}$ African Migration 'a Trickle' Thanks to Trafficking Ban Across the Sahara, BBC (Jan. 11, 2019), https://www.bbc.com/ news/world-africa-46802548.

${ }^{46}$ Paul Craig \& Gráinne de Burca, EU law: Text, Cases, and Materials 322 (6th ed. 2015).

${ }^{47}$ See Treaty on the Functioning of the European Union arts. 2(2), 4(2)(j), Oct. 26, 2012, 2012 O.J. (C 326) [hereinafter TFEU].

${ }^{48}$ Paul J. Cardwell, EU External Relations and Systems of Governance 170 (2009); Sergio Carrera et al., The External Dimensions of EU Migration and Asylum Policies in Times of Crisis, in Constitutionalising THE EXTERnAL Dimensions of EU Migration Policies in Times of Crisis: Legality, Rule of Law and Fundamental Rights Guarantees 1, 9 (Sergio Carrerra et al. eds., 2019). See also Paula Garcia Andrade, EU External Competences on Migration: Which Role for Mixed Agreements?, in Constitutionalising the EXTERnal Dimensions of EU MigRation Policies in Times of Crisis: Legality, Rule of Law and Fundamental Rights Guarantees 39 (Sergio Carrerra et al. eds., 2019).

${ }^{49}$ TFEU at art. 79(3).

${ }^{50}$ TFEU at art. 216(1). See Marise Cremona, Defining Competence in EU External Relations: Lessons from the Treaty Reform Process, in Law and Practice of EU External Relations: Salient Features of a Changing Landscape 34 (Alan Dashwoord \& Marc Maresceau eds., 2008); Andrade, supra note 48, at 39, 40.

${ }^{51}$ See Andrade, supra note 18; EU External Migration Policies in an Era of Global Mobilities: InTERSECTING Policy UNIVERSES (Sergio Carrera et al. eds., 2018).
} 
taken within the latter or within the Area of Freedom, Security and Justice, of which migration explicitly forms part, is also unclear. The Common Foreign and Security Policy has been used for regulating migration matters, ${ }^{52}$ while the field of migration falls within the Area of Freedom, Security and Justice. ${ }^{53}$ The absence of clear legal boundaries between the two areas is detrimental to legal certainty. ${ }^{54}$ In sum, the overlapping nature of national competences, EU competences, competences shared between the MS and the EU, and how these competences can be legally framed create confusion.

At the same time, in practice, many EU cooperation instruments with third countries in the field of migration include the participation of both the EU and the MS, ${ }^{55}$ such as the Mobility Partnership signed in March 2014 between Tunisia, the EU, and ten MS. ${ }^{56}$ In parallel with the $\mathrm{EU}$, the MS also undertake individual measures and develop external actions on migration at a bilateral level with third countries. ${ }^{57}$ Some of these actions might be reproduced by the EU.

The ultimate problem is the uncertainty as to the legal basis for these measures. If there is no clarity as to the legal basis, there is also ambiguity as to which actor-the EU or the MS - has undertaken the measure. ${ }^{58}$ From a human rights law perspective and from the perspective of the EU Charter, this ambiguity creates problems. In particular, it makes it difficult to answer the question: Against which actor can any human rights claim be raised? The response to this question in turn is crucial in assessing the applicability of the EU Charter. As the next section will show, if it is the EU or EU bodies that have undertaken the measures, then it might be easier to trigger the application of the Charter. If it is the MS, then the activation of the Charter is more questionable.

Finally, if the EU Charter is formally triggered because the conditions in Article 51(1) are fulfilled, then an independent and separate assessment can be made as to the conduct of each actor-the EU, its bodies, and the MS. Positive obligations can be very useful for separating the conduct of each actor in light of this actor's competences. ${ }^{59}$ And given the limited competence of the EU, any positive obligations upon it need to be based on and within the boundaries of this limited competence. ${ }^{60}$

\section{Informality}

Besides extraterritoriality and involvement of many actors, the third factor that characterizes the cooperation-based measures aimed at combatting human smuggling is informality. Informality is

\footnotetext{
${ }^{52}$ Graham Butler, Forcing the Law to Overlap? EU Foreign Policy and Other EU External Relations in Times of Crisis, in Irregular Migration as a Challenge to Democracy 51 (Elzbieta Kuzelewska et al. eds., 2018).

${ }^{53}$ P. J. Cardwell, Rethinking the Law and New Governance in the EU: The Case of Migration Management, 41 EUR. L. REV. 362, 368 (2016).

${ }^{54}$ Luigi Lonardo, Common Foreign and Security Policy and the EU's External Action Objectives: An Analysis of Article 21 of the Treaty on the EU, 14 Eur. CONST. L. REv. 584, 598 (2018).

${ }^{55}$ Study for the LIBE Committee, supra note 1, at 10.

${ }^{56}$ Study for the LIBE Committee, supra note 1, at 95.

${ }^{57}$ Study for the LIBE Committee, supra note 1, at 64; see Spagnolo, supra note 24.

${ }^{58}$ This ambiguity also creates procedural problems because, in principle, the EU Court of Justice-with two exceptions indicated in Article 275 TFEU-does not have competence over the Common Foreign and Security Policy. The Court thus might be precluded from assessing whether the measures taken within this policy field are compatible with the EU Charter. See Butler, supra note 17, at 290. This Article does not engage with procedural questions, and this issue will not be explored further.

${ }^{59}$ This has been the approach followed by the ECtHR in cases involving multiple states that have together contributed to harm sustained by individuals. Maarten den Heijer, Shared Responsibility before the European Court of Human Rights, 60 Netherlands INT'L L. ReV. 411, 416 (2013).

${ }^{60} \mathrm{See}$ Charter of Fundamental Rights of the European Union, June 7, 2016, 2016 O.J. (C 202) (in Article 51(2) barring an interpretation of the Charter that leads to the conferral of new competences to the EU). See also Joined Cases C-8/15 P, C-9/15 P \& C-10/15 P, Ledra Advert. v. Eur. Comm'n, 2016 E.C.R. at para. 70; Fink, supra note 17, at 278; MALU BEIJER, THE LIMITS of Fundamental Rights Protection by the EU: The Scope for the Development of Positive Obligations, 112, 179220 (2017).
} 
understood as the avoidance of formal procedures and absence of concrete legal basis for the adoption of the measures of containment. ${ }^{61}$ It needs to be initially acknowledged that some aspects of the external dimension of migration control measures have been based on legally binding instruments, including specific EU legislation ${ }^{62}$-as in the case of Operation Sofia, ${ }^{63}$ a Common Security and Defense Policy mission. Nonetheless, the external dimension of the EU migration policy has mainly been shaped by instruments with unclear legal basis and unclear legal value, ${ }^{64}$ and by informal policy arrangements. ${ }^{65}$

The agreements arranged by the EU and the MS with third countries are difficult to characterize legally because they are not always international agreements or treaties in the traditional sense. Such arrangements are not opened, negotiated, and ultimately concluded in accordance with the procedure in Article 218 of the TFEU. ${ }^{66}$ Examples include mobility partnerships, action plans, memoranda of understanding, ${ }^{67}$ migration dialogues, common agendas on migration and mobility, nonpapers, ${ }^{68}$ and "joint communiqués." 69 These examples can be characterized as "quasi-legal or sui generis soft policy tools which are in most cases nonlegally binding for the parties involved and whose legal effects remain dubious." 70 The most prominent example of such a soft law, non-legally binding instrument veiled in uncertainty is the EU-Turkey Statement of March 18, 2016 thatdespite its name - was found by the Court of Justice not to be an act of an EU institution. ${ }^{71}$

The informal nature of the arrangements with third countries presents challenges regarding the possibility for reviewing the measures under the EU Charter. The controversial question is whether EU institutions and bodies are bound by the Charter when they act outside the EU legal framework. ${ }^{72}$ Another issue arises when it is uncertain as to whether they act within their competence. ${ }^{73}$ If the EU Charter is applicable even if the EU acts beyond its competence as conferred by the Treaties, this implies that EU bodies and institutions owe obligations under the Charter

\footnotetext{
${ }^{61}$ Juan S. Vara, Soft International Agreements on Migration Cooperation with Third Countries: A Challenge to Democractic and Judicial Controls in the EU, in COnstitutionalising the EXternal Dimensions of EU Migration Policies in Times of Crisis: Legality, Rule of Law and Fundamental Rights Guarantees 21 (Sergio Carrera et al. eds., 2019); Elaine Fahey, Hyper-Legislation and De-Legalisation in the AFSJ: On Contradictions in EU External Migration Law, in Constitutionalising the External Dimensions of EU Migration Policies in Times of Crisis: Legality, Rule of LAW AND Fundamental Rights GuaranteEs 116 (Sergio Carrera et al. eds., 2019).

${ }^{62}$ Study for the LIBE Committee, supra note 1, at 35.

${ }^{63}$ Council Decision 2015/778, of 18 May 2015 on the EU Military Operation in the Southern Central Mediterranean, 2015 O.J. (L 122/31). For the relevant current legal basis, see Regulation 2016/1624 of 14 September 2016 on the European Border and Coast Guard, 2016 O.J. (L 251).

${ }^{64}$ Butler, supra note 52 , at 61 .

${ }^{65}$ Study for the LIBE Committee, supra note 1 , at 10.

${ }^{66}$ Butler, supra note 17, at 288; Sergio Carrera et al., The External Dimension of EU Migration and Asylum Policies in Times of Crisis, in Constitutionalising the External Dimensions of EU Migration Policies in Times of Crisis: Legality, Rule of LaW and Fundamental Rights Guarantees 1, 11 (Segio Carrera et al. eds., 2019).

${ }^{67}$ Jorrit J. Rijpma \& M. Cremona, The Extra-Territorialisation of EU Migration Policies and the Rule of Law (EUI Working Paper Series, Working Paper No. 1, 2007).

${ }^{68}$ European External Action Service, Non-Paper: Options on Developing Cooperation with Egypt in Migration Matters (2016), available at https://www.statewatch.org/news/2016/dec/eu-com-eeas-non-paper-egypt-migration-cooperation.pdf.

${ }^{69}$ See, e.g., Koenders Concludes Migrant Return Agreement with Mali for EU, GovernMENT OF THE NETHERLANDS (Dec. 11, 2016) https://www.government.nl/latest/news/2016/12/11/koenders-concludes-migrant-return-agreement-with-mali-for-eu.

${ }^{70}$ Directorate-General for Internal Policies, Implementation of the EU Charter of Fundamental Rights and its Impact on EU Home Affairs Agencies: Frontex, Europol and the European Asylum Support Office, at 101 (2011), http://www.europarl.europa. eu/RegData/etudes/etudes/join/2011/453196/IPOL-LIBE_ET(2011)453196_EN.pdf.

${ }^{71}$ Case T-192/16, NF v. Eur. Council, Case T-193/16 NG v. Eur. Council, 2017 E.C.R. 28 (2017). See Thomas Spijkerboer, Bifurcation of People, Bifurcation of Law: Internationalization of Migration Policy before the EU Court of Justice, 31 J. REFUGEE Stud. 216, 222 (2018); Enzo Cannizzaro, Disintegration through Law?, 1 EUR. PAPERs 3 (2016).

${ }^{72}$ Ledra Advert., Joined Cases C-8/15 P \& C-10-15 P at para 67. See also Steve Peers, Towards a New Form of EU Law?: The Use of EU Institutions outside the EU Legal Framework, 9 EUR. CONST. L. REV. 37 (2013).

${ }^{73} \mathrm{Id}$.
} 
by the mere fact that they in practice act, even if it is questionable whether they are legally allowed to undertake these acts, because the latter might be beyond their competences. A different interpretation could lead to "legal black holes," where the EU acts, but without the application of the guarantees under the EU Charter. ${ }^{74}$ A textual interpretation also might be helpful here. The words "only when they [the MS] are implementing Union law" in Article 51(1) of the Charter, arguably apply solely to the MS, not to the EU institutions. This interpretation would mean that "the EU institutions would be bound by the Charter whether they are implementing Union law or not."75

Ledra Advertising is an important judgment to consider in this context. The subject matter of the judgment is not related to migration control. Nevertheless, the issue as to whether the Charter applies to EU institutions and bodies when they act outside of the EU legal framework was specifically addressed. The judgment concerns an action brought against the EU Commission and the European Central Bank for their role played in the process of the adoption of a memorandum of understanding concluded between Cyprus and the European Stability Mechanism. This memorandum arguably breached the right to property as protected by the EU Charter because account holders in Cyprus lost part of their savings after the restructuring of the Cypriot banks and the bail out. The Court of Justice in Ledra Advertising held that:

[W]hilst the Member States do not implement EU law in the context of the ESM Treaty, so that the Charter is not addressed to them in that context..., on the other hand the Charter is addressed to the EU institutions, including as the Advocate General has noted in point 85 of his Opinion, when they act outside the EU legal framework. Moreover, in the context of the adoption of a memorandum of understanding such as that of 26 April 2013, the Commission is bound... to ensure that such a memorandum of understanding is consistent with the fundamental rights guaranteed by the Charter. ${ }^{76}$

The relevance of this judgment is that the EU institutions do not escape scrutiny under the EU Charter when they act outside the EU legal framework by concluding informal agreements, such as the memoranda of understanding. ${ }^{77}$ It follows that any act-including negotiations and conclusions of agreements-produced by an EU institution or body must comply with the Charter. The reason is that in contrast to the MS that are bound by the Charter only when implementing EU law, the EU institutions and bodies must respect fundamental rights regardless of the specific legal framework or context in which they operate- "[i]nformal acts are also encompassed as long as they are products of EU institutions and have legal effects."78

Turning to the applicability of the Charter to the MS's role in the informal arrangements that characterize the anti-smuggling measures, the first thing to note is that the Charter does not "create 'free-standing' fundamental rights." ${ }^{\prime 9}$ Rather, the rights in the Charter are tied to the field of application of EU law. This means that "[t]here must be a provision or a principle of Union primary or secondary law not contained in the Charter which is directly relevant to the case," 80 for the Charter to be applicable to the MS. The key questions for triggering the application of the

\footnotetext{
${ }^{74}$ Moreno-Lax \& Costello, supra note 40, at 1682.

${ }^{75}$ Peers, supra note 72 , at 52.

${ }^{76}$ Ledra Advert., Joined Cases C-8/15 P \& C-10-15 P at para. 67 (emphasis added).

${ }^{77}$ Anastasia Poulou, The Liability of the EU in the ESM Framework, 24 MAASTRICHT J. EUR. \& COMP. L. 127 (2014).

${ }^{78}$ Anastasia Poulou, Financial Assistance Conditionality and Human Rights Protection: What is the Role of the EU Charter of Fundamental Rights, 54 Common MKT. L. REv. 991, 1010 (2017).

${ }^{79}$ Koen Lenaerts \& Antonio Guitierrez-Fons, The Place of the Charter in the EU Constitutional Edifice, in THE EU CHARTER of Fundamental Rights: A Commentary 1592 (Steve Peers et al. eds., 2014).

${ }^{80}$ Allan Rosas, The Applicability of the EU Charter to Fundamental Rights at National Level, 19 EUR. Y.B. HUM. RTS. 97, 105 (2013); Steve Peers, Immigration, Asylum and the EU Charter of Fundamental Rights, in ThE FIRST DECADE OF EU MIGRATION AND Asylum LAw 437, 449 (Elspeth Guild \& E.P. Minderhoud, eds., 2012); Case C-617/10, Åkerberg Fransson v. Sweden, 2013 E.C.R. at paras. 19, 21; Craig \& de Burca, supra note 46, at 416.
} 
Charter to the MS are the following: Are the MS implementing EU law with the anti-smuggling measures that affect individuals located in third countries? Do the anti-smuggling measures based on cooperation with third countries have a connection to EU law that might enable their review against the standards of the EU Charter? If these measures are outside any legal framework-a problem described above-then this means that when MS make arrangements with third countries to contain movement, the measures are not implemented by the EU, thereby excluding them from the scope of the Charter.

It might, however, be relevant to consider that the EU is signatory to the UN Smuggling Protocol, ${ }^{81}$ which implies that the provisions of the Protocol form an integral part of Community law. ${ }^{82}$ Given the declaration deposited by the EU on the extent of its competence with respect to matters governed by the Protocol, ${ }^{83}$ cooperation by MS with third countries could be framed as being in implementation of the Smuggling Protocol, as part of EU law.

\section{The Positive Obligation to Prevent Loss of Life}

Having clarified that the Charter may be applicable, it is relevant to analyze the standards raised by it. Given that - within the context of the anti-smuggling measures described in Part B-agents of the EU and the MS do not take actions that directly lead to migrants' deaths, how the deaths and the risk of death relate to any positive obligations to protect the right to life owned by the EU and the MS needs to be explored. These obligations are relevant in circumstances when a third partysuch as a third state or a private party, like a smuggler - takes measures that infringe the interests protected by the right or that pose risks to these interests. Under such circumstances, the EU and the MS might be in violation of the EU Charter for having failed to take proactive measures to prevent deaths or reduce the risk.

\section{The Positive Obligation of Adopting Effective Regulatory Framework}

The analysis of Article 2 of the EU Charter-which enshrines the right to life-must start with a careful consideration of the implications from Article 52(3) of the same instrument. The latter ensures a consistency in the interpretation of the rights enshrined in the EU Charter and the ECHR. As the Explanatory Note to Article 52(3) clarifies, "the meaning and the scope of the guaranteed rights are determined not only by the text of those instruments, but also by the case-law of the European Court of Human Rights and by the Court of Justice of the European Union." ${ }^{84}$ In its case law under Article 2 of the ECHR protecting the right to life, the ECtHR has applied positive obligations, developed in situations when state authorities are expected to prevent death or risk to life, or to reduce this risk. ${ }^{85}$ In light of Article 52(3) of the Charter, the right to life under Article 2

\footnotetext{
${ }^{81}$ See Council Decisions 2006/616/EC and 2006/617/EC of July 24 2006, 2006 O.J. (L 262).

${ }^{82}$ Mario Mendez, The Legal Effect of Community Agreements: Maximalist Treaty Enforcement and Judicial Avoidance Techniques, 21 EUR. J. INT'L L. 83, 86 (2010).

${ }^{83}$ European Union, Declaration, Jan. 28, 2004, 2241 U.N.T.S. 507, https://treaties.un.org/doc/Publication/MTDSG/Volume \%20II/Chapter\%20XVIII/XVIII-12-b.en.pdf.

${ }^{84}$ Steve Peers \& Sacha Prechal, Article 52, in The EU Charter of Fundamental Rights: A Commentary 1455, 1494-95, 1498 (Steve Peers et al. eds., 2014). See also Case C-400/10, J. McB. v. L.E., 2010 E.C.R I-8992, at para. 53.

${ }^{85}$ On positive obligations under the ECHR more generally, see Alastair R. Mowbray, The Development of Positive Obligations under the European Convention on Human Rights (2004); Laurens Lavrysen, Human Rights in a Positive State (2016); Cordula Dröge, Positive Verpflichtungen der StaAten in der Europäischen Menschenrechtskonvention (2003); Vladislava Stoyanova, Human Trafficking and Slavery Reconsidered: Conceptual Limits and States Positive Obligations in European Law 329 (2017); Dimitris Xenos, The Positive Obligations of the State under the European Convention of Human Rights (2011).
} 
also triggers positive obligations. ${ }^{86}$ To understand its relevance and scope, a scrutiny of the ECtHR case law on this matter is helpful.

The ECtHR has formulated in its case law a positive obligation upon the state to adopt effective regulatory frameworks to prevent loss of life. This positive obligation applies to circumstances when there are some general structural risks against the population at large and the state is aware- or should have been aware - that these risks might lead to deaths. ${ }^{87}$ To this effect, the ECtHR has used the following formulation:

This positive obligation entails above all a primary duty on the State to put in place a legislative and administrative framework designed to provide effective deterrence against threats to the right to life .... This obligation must be construed as applying in the context of any activity, whether public or not, in which the right to life may be at stake. ${ }^{88}$

The specific content of this positive obligation depends on the particular circumstances in which the risk to life arises. For example, this positive obligation has been found to have been breached in circumstances when individuals have lost their lives due to natural hazards—like mudslides ${ }^{89}$ —or industrial activities when the state had not taken preventive protective measures. ${ }^{90}$

The positive obligation of adopting effective regulatory framework to prevent loss of life serves general preventive functions. The ECtHR has observed that "what is at issue is the obligation to afford general protection to society." 91 There is no requirement that there is a real and immediate risk for an identifiable individual or identifiable group of individuals. ${ }^{92}$ This lack of a requirement is important, because migrants who lose their lives while being smuggled are not likely to be specifically and individually identifiable in advance. ${ }^{93}$

\section{Reasonableness, Knowledge, and Causation}

Although the positive obligation to protect life applies to all possible circumstances, no unreasonable expectations can be raised against the state in relation to its capacity to protect life. As the ECtHR has clarified, no "impossible or disproportionate burden" can be imposed on the state authorities. It is thus necessary to consider the choices that these authorities need to make in terms of priorities and resources. ${ }^{94}$ Competing interests can therefore limit the scope of the positive

\footnotetext{
${ }^{86}$ See generally Fink, supra note 17 , at 277.

${ }^{87}$ Öneryildiz v. Turkey, App. No. 48939/99, para. 89 (Nov. 30, 2004); Budayeva and Others v. Russia, App. Nos. 15339/02, 21166/02, 20058/02, 11673/02 \& 15343/02, paras. 128-29 (Mar. 20, 2008).

${ }^{88}$ Budayeva, App. Nos. 15339/02, 21166/02, 20058/02, 11673/02 \& 15343/02 at paras. $129-30$.

${ }^{89} \mathrm{Id}$. at paras. $146-60$.

${ }^{90}$ Öneryildiz, App. No. 48939/99.

${ }^{91}$ Mastromatteo v. Italy, App. No. 37703/97, para. 69 (Oct. 24, 2002). See Section C.III, where I explain that in principle, this positive obligation has been developed in domestic settings and questions remain open as to its application in extraterritorial settings.

${ }^{92} I d$. at para 39. The Court has developed a separate positive obligation of taking protective operational measures under Article 2 ECHR; this obligation is triggered when a particular individual is at real and immediate risk of harm. See Vladislava Stoyanova, Causation between State Omission and Harm within the Framework of Positive Obligations under the European Convention on Human Rights, 18 Hum. RTs. L. REv. 309 (2018). For clarifications as to the standards for triggering the positive obligation of taking protective operational measures, see Franz Ebert \& Romina Sijniensky, Preventing Violations of the Right to Life in the European and Inter-American Human Rights Systems: From the Osman Test to a Coherent Doctrine on Risk Prevention?, 15 Hum. RTs. L. Rev. 343 (2015).

${ }^{93}$ Circumstances can be imagined where a group of migrants can be identifiable in advance as being at risk. For example, when this group has already managed to depart from the Libyan coast in an unseaworthy boat.

${ }^{94}$ Budayeva, App. Nos. 15339/02, 21166/02, 20058/02, 11673/02 \& 15343/02, para. 135; Vladislava Stoyanova, Common Law Tort of Negligence as a Tool for Deconstructing Positive Obligations under the European Convention on Human Rights, INT'L J. HuM. RTs. (forthcoming).
} 
obligations corresponding to the right to life, and immigration control can be part of these competing interests ${ }^{95}$ - a point to which I will return below.

The consideration of reasonableness is closely connected to two other factors: (1) Official knowledge or awareness about the harm and its likelihood; and (2) causal links between the harm and the state's conduct - an example of such conduct being "omission." As to knowledge, the ECtHR has consistently reiterated that the positive obligations under the ECHR arise when the state authorities knew or ought to have known about the risk of harm. ${ }^{96}$ This could imply that the risk of harm was objectively foreseeable and the state should have known about it. Alternatively, the state should have known about the risk because it should have undertaken steps - in the form of studies or something similar in nature - to foresee the risk. ${ }^{97}$ The more foreseeable the risk to life, the more reasonable it is to expect the state to take measures to prevent loss of life. ${ }^{98}$ In relation to migrants who lose their lives while trying to reach destination states via human smuggling, there is little doubt that the EU and the MS are aware of the risks to life and, in this sense, the requirement for foreseeability of the risk is fulfilled.

Causation is important in the context of positive obligations because an alleged omission by the state is at the core of the analysis, and attention needs to be paid to how this omission contributed to harm. As to the causal relationship between harm - in the form of death or risk of death-and state's conduct - in the form of omission ${ }^{99}$ - the ECtHR has not established a concrete test. It has, however, explicitly rejected a "but for" test, meaning that there is no requirement that but for the state's failure or omission the harm would not have happened. ${ }^{100}$ For the rest, the requirement of causation has been framed in different ways in different judgments. For example, in Budayeva and Others $v$. Russia, the causation was expressed in terms of a causal link between the serious administrative flaws that impeded the implementation of land-planning and emergency relief policies and the death and injuries sustained by the applicants. ${ }^{101}$ In other judgments, the Court has referred to the expressions "due to" - a breach of positive obligation will be found only if the harm was "due to insufficient regulations or insufficient control"102_and "direct causal link." 103 It has also referred to measures that "might have been expected to avoid that risk." 104 Overall, the ECtHR has been far from rigid in the assessment of causal linkages between state omissions and harm, but has rather shown a great deal of flexibility. ${ }^{105}$

This flexibility can be understood in light of certain normative considerations that permeate the case law. As Lavrysen has observed, causation by omission necessarily involves normative assessment "to determine those relevant omissions that can be considered as causes."106

\footnotetext{
${ }^{95}$ For a general discussion on how positive obligations under human rights law can be shaped by immigration control considerations, see Stoyanova, supra note 85, at 380.

${ }^{96}$ Ctr. for Legal Res. on Behalf of Valentin Câmpeanu v. Romania, App. No. 47848/08, para. 130 (July 17, 2014).

${ }^{97}$ For these distinctions, see Vladislava Stoyanova, Fault, Knowledge and Risk within the Framework of Positive Obligations under the European Convention on Human Rights, LEIDEN J. INT'L L. (forthcoming 2020).

${ }^{98}$ Stoyanova, supra note 92 , at 315 . See also Lavrysen, supra note 85 , at 138.

${ }^{99}$ For the importance of the requirement for causation, see L.C.B. v. The United Kingdom, App. No. 14/1997/798/1001, para. 40 (June 9, 1998).

${ }^{100}$ E. and Others v. The United Kingdom, App. No. 33218/96, para. 99 (Nov. 26, 2002).

${ }^{101}$ Budayeva, App. Nos. 15339, 21166/02, 20058/02, 11673/02 \& 15343/0 at para. 158 (Mar. 20, 2008).

${ }^{102}$ Stoyanovi v. Bulgaria, App. No. 42980/04, para. 61 (Nov. 9, 2010).

${ }^{103}$ Dodov v. Bulgaria, App. No. 59548/00, para. 97 (Jan. 17, 2008).

${ }^{104}$ Kemaloglu v. Turkey, App. No. 19986/06, para. 36 (Apr. 10, 2012).

${ }^{105}$ This has also led to the critique that positive obligations under the ECHR are uncertain and unpredictable. See, e.g., Pieter van Dijk, "Positive Obligations" Implied in the European Convention on Human Rights: Are the States Still the 'Masters' of the Convention?, in The Role of the Nation-State in the 21st Century: Human Rights, International Organizations and Foreign Policy: Essays in Honour of Peter Baehr 17, 22 (Monique Castermans-Holleman et al. eds., 1998).

${ }^{106}$ See also Lavrysen, supra note 85, at 140; Stoyanova, supra note 97.
} 
Certain underlying normative considerations can therefore shape the approach to causation. ${ }^{107}$ These considerations might relate to certain expectations regarding the role of the state more generally. Protecting the borders of the bounded national community could be one such expectation, an important point to which I will return below. The level of control that the state has over certain events, people, and circumstances can also influence the approach to causation ${ }^{108}$ —another relevant consideration that I will return to in Part D.

\section{Extraterritorial Application of Positive Obligations}

One final clarification regarding causation is due. These flexible causation standards have been developed in circumstances when no issues of extraterritoriality arise. Thus, there is uncertainty as to how the substantive positive obligation to protect life-and the requirement for causation between harm and state omissions-could apply to individuals located beyond the state's borders in relation to which no territorial or personal control has been established. ${ }^{109}$

Tugar $v$. Italy is a case that could provide some insights, as it concerned a mine clearer who lost his leg in Iraq after stepping on an anti-personnel mine of Italian origin. ${ }^{110}$ The applicant argued that Italy-having omitted to regulate the private company that supplied Iraq with the lethal weapons-failed to protect him by means of an effective transfer licensing system and, as a consequence, Italy did not comply with its positive obligations under Article 2 ECHR. In declaring the application inadmissible, the European Commission on Human Rights reasoned that:

[T] he applicant's injury cannot be seen as a direct consequence of the failure of the Italian authorities to legislate on arms transfers. There is no immediate relationship between the mere supply, even if not properly regulated, of weapons and the possible "indiscriminate" use thereof in a third country, the latter's action constituting the direct and decisive cause of the accident which the applicant suffered. It follows that the "adverse consequences" of the failure of Italy to regulate arms transfers to Iraq are "too remote" to attract the Italian responsibility. ${ }^{111}$

Pursuant to this reasoning, there were important intervening acts that hampered the causation between the harm and the alleged failure by Italy: First, it was an Italian private company that delivered the weapons-subsequently found guilty of illegal arms trafficking to Iraq by an Italian court; second, it was Iraq that mined the area; and third, this mining was done in an indiscriminate way. In this sense, there was no conduct by the respondent state that "may directly expose a particular individual to a particular and immediate risk."112

Admittedly, the Commission's reasoning in Tugar v. Italy lacks clarity, because it seems to conflate the threshold issue of jurisdiction with issues pertaining to the substantive analysis, such as causation in the context of positive obligations. Even if the threshold question of jurisdiction is set aside-because arguably, as explained in Section B.I, it is irrelevant for the EU Charter-the

\footnotetext{
${ }^{107}$ Authors have noted the role of normative and policy considerations in the determination of causal links. See Sandy Steel, Causation in Tort Law and Criminal Law: Unity and Divergence?, in UnRAvelling TORT AND CRIME 239 (Matthew Dyson ed., 2014); Richard Fumerton \& Ken Kress, Causation and the Law: Preemption, Lawful Sufficiency, and Causal Sufficiency, 64 L. \& Contemp. Problems 83 (2001).

${ }^{108}$ See generally Stoyanova, supra note 92.

${ }^{109}$ Perhaps for this reason, Milanovic has proposed that the jurisdictional threshold under Article 1 ECHR can be discarded in relation to negative obligations upon the state, but it needs to be retained in relation to states' positive obligations. See Marko Milanovic, Extraterritorial Application of Human Rights Treaties (2011).

${ }^{110}$ Tugar v. Italy, App. No. 22869/93 (Oct. 18, 1995) (inadmissible).

${ }^{111} I d$. (emphasis added).

${ }^{112} I d$. The reference to a particular individual appears inconsistent with the nature of the positive obligation of general prevention, as explained in Section C.I. To formulate this reference, the Commission in Tugar v. Italy drew on Soering $v$. United Kingdom, 161 Eur. Ct. H.R. (1989), where the decision to extradite did concern a particular individual.
} 
causation standard appears to be demanding through the expressions "direct consequence" and "immediate relationship." Yet it would be premature to draw more general conclusions from Tugar v. Italy. Overall, the test for determining the causation between omissions by states and extraterritorial harm in the context of positive obligations is fraught with uncertainties, including in relation to the EU Charter. The next section attempts to offer reflections relevant to the loss of life in the context of anti-smuggling measures.

\section{The Application of this Positive Obligation to the Anti-Smuggling Measures}

\section{Conflicting Lines of Causation}

The exploration of the causal link between loss of life and conduct by the EU and the MS can start with the general acknowledgement that if movement across borders were not irregularized by countries of destination, migrants would likely not resort to irregular means of travel. Migrants would prefer regular and safe migration channels. If there were legal routes, it is less likely that they would risk their lives to reach countries of destination. ${ }^{113}$ Normatively, however, the leverage of this explanation is limited because states are entitled to control their borders and human rights law accommodates states' migration control interests. ${ }^{114}$ Thus, the right to life cannot trigger a positive obligation of generally dismantling borders. Any positive obligation in this context has to be somehow adjusted to destination states' migration control interests. For this reason, the positive obligation has to be more restricted in its scope. This will be further explained in Section D.V below.

Without generally challenging destination states' migration control entitlement, it can be argued that the particular modalities of the anti-smuggling measures undertaken by countries of destination make irregular travel even more dangerous. For example, criminalization arguably prompts smugglers to find techniques to avoid arrest by, for example, letting the migrants steer the boat themselves or offloading migrants before reaching the shore. ${ }^{115}$ Destruction of boatsanother anti-smuggling measure ${ }^{116}$-might discourage smugglers from investing in boats and instead push them to use boats that are of poor quality-like rubber dinghies - or just inadequately equipped. ${ }^{117}$ In addition, the increased surveillance of the departure coast might prompt smugglers to use more dangerous routes or choose to depart in bad weather conditions, which can also increase the risk to life. ${ }^{118}$ The withdrawal of search and rescue-or the obstruction of the

\footnotetext{
${ }^{113}$ Paolo Cuttitta et al., Various Actors: The Border Death Regime, in Border DeATHS: CAUSES, DyNAMICS AND Consequences of Migration-Related Mortality 35, 39 (Paolo Cuttitta \& Tamara Last eds., 2019).

${ }^{114}$ Stoyanova, supra note 85, at 384; Ilias \& Ahmed v. Hungary, App. No. 47287/15, para. 213 (Mar. 14, 2017) ("It is important in particular to recognize the States' right, subject to their treaty obligations, to control their borders and to take measures against foreigners circumventing restrictions on immigration.").

${ }^{115}$ Derek Lutterbeck, Policing Migration in the Mediterranean, 11 Mediterranean Pol. 59, 69 (2006); Martin BaldwinEdwards \& Derek Lutterbeck, Coping with the Libyan Migration Crisis, 45 J. Ethnic \& Migration STUd. 2241, 2253 (2019); Liz Fekete, Deaths at Europe's Borders, 45 RaCE \& CLASS 75, 79 (2004).

${ }^{116}$ Operation Sophia's mandate includes the destruction of boats. See European External Action Service, Factsheet on EUNAVFOR MED Mission (Apr. 25, 2017), https://eeas.europa.eu/sites/eeas/files/april_2017_-_factsheet_on_eunavfor_ med_mission_english.pdf. The destruction of wooden boats has arguably led to the usage of cheaper rubber dinghies. See Stuart A. Thompson \& Anjali Singhvi, Efforts to Rescue Migrants Caused Deadly, Unexpected Consequences, New York TIMES (June 14, 2017), https:/www.nytimes.com/interactive/2017/06/14/world/europe/migrant-rescue-efforts-deadly.html.

${ }^{117}$ Cuttitta et al., supra note 113 , at 45 .

${ }^{118}$ See Zach Campbell, Europe's Deadly Migration Strategy: Officials knew EU military operations made Mediterranean crossing more dangerous, Politico (Feb. 28, 2019), https://www.politico.eu/article/europe-deadly-migration-strategyleaked-documents/. For academic literature that maintains that smuggling routes are made more dangerous, see Stefanie Grant, Recording and Identifying European Frontier Deaths, 13 Eur. J. MigRation \& L. 135, 139 (2011); Tamara Last \& Thomas Spijkerboer, Tracking Deaths in the Mediterranean, in FATAL Journeys 85 (Tara Brian \& Frank Laczko eds., 2014); Spijkerboer 3, supra note 9, at 127. For further review of the literature, see Tamara Last, Deaths Along Southern EU Borders 82-86 ( $\mathrm{PhD}$ thesis defended at Vrije Universiteit, 2018), available at https://research.vu.nl/en/publications/ deaths-along-southern-eu-borders.
} 
activities of actors that perform search and rescue, which have been also framed as measures that prevent human smuggling ${ }^{119}$ — can also, arguably, increase the risk to life. ${ }^{120}$

EU policy documents, however, provide a different picture. The assumption underlying these documents is that cooperation with third states and the involved anti-smuggling measures discourage and prevent people from migrating through irregular channels. ${ }^{121}$ This cooperation arguably leads to fewer people using smuggling and decreases the risk to life because fewer people are likely to die while, for example, crossing the sea. The smugglers are thus represented as the actors who put migrants at risk. ${ }^{122}$

In sum, there are two explanations. ${ }^{123}$ According to the first, more anti-smuggling measures and border controls in general lead to more deaths and higher risk to life. According to the secondreflected in the EU policy documents-more border controls and more robust anti-smuggling measures lead to fewer deaths and less risk. ${ }^{124}$ Both explanations are difficult to substantiate with concrete empirical studies that can conclusively prove the assumed causal connections. ${ }^{125}$ This is also an important point to which I will return in Section D.V below.

\section{Uncertain and Remote Causation}

Given the objective of establishing the responsibility of the EU and the MS for loss of life or risk to life, the complexity of the causation lines is further exacerbated. Even if the antismuggling measures increase the risk to life, the EU's and the MS's involvement in the performance of some of these measures is indirect-through the provision of equipment, intelligence, and financial support to third states. As explained in Part B, it is actually third countries that are directly engaged in the actual control of the borders, the interception of migrants, the confiscation of vehicles, or the prevention of search and rescue efforts by NGOs. ${ }^{126}$ Under these circumstances, the causality between the EU's and MS's conduct and any harm might be too remote. If the Tugar v. Italy

\footnotetext{
${ }^{119}$ According to FRONTEX, search and rescue missions "close to, or within, the 12-mile territorial waters of Libya have unintended consequences. Specifically, they influence smugglers' planning and act as a pull factor that compounds the difficulties inherent in border control and saving lives at sea." Frontex: European Border and Coast Guard, Risk Analysis for 2017 (Feb. 2017), https://frontex.europa.eu/assets/Publications/Risk_Analysis/Annual_Risk_Analysis_2017.pdf. For a rejection of the argument that search and rescue operations act as a pull factor, see Eugenio Cusumano \& James Pattison, The NonGovernmental Provision of Search and Rescue in the Mediterranean and the Abdication of State Responsibility, 31 Cambridge Rev. Int'L Aff. 53, 64 (2018); Eugenio Cusumano \& Mateo Villa, Sea Rescue NGOs: A Pull Factor of Irregular Migration? (Migration Policy Ctr. Pol'y Brief 2019/22, 2019).

${ }^{120}$ Paolo Cuttitta, Repoliticization through Search and Rescue? NGOs and Humanitarian Migration Management in the Central Mediterranean, 23 GEOPOLITICS 632 (2018).

${ }^{121}$ Communication from the Commission Progress Report on the Implementation of the European Agenda on Migration, at 12, COM (2019) 126 final (Mar. 6, 2019).

${ }^{122}$ See generally Last, supra note 118, at 88-90. The role of the smugglers in contributing to the risks cannot be ignored. See Chris Horwood, Angels or Devils? A More Honest Appraisal of the Role of Migrant Smugglers, in MiXed MigRATION ReVIEW 2018122 (Mixed Migration Centre ed., 2018).

${ }^{123}$ For a useful outline, see Kristof Gombeer et al., Understanding the Causes of Border Deaths, in BORDER DEATHS: CAUSES, Dynamics ANd Consequences of Migration-Related Mortality 131 (Paolo Cuttitta \& Tamara Last eds., 2019).

${ }^{124}$ The Commission has emphasized that the number of deaths has decreased since 2016 due to the EU's and the MS's efforts, including the cooperation with third countries. See Communication from the Commission Progress Report on the Implementation of the European Agenda on Migration, at 4, COM (2019) 126 final (Mar. 6, 2019). It is difficult, however, to prove the actual reasons for the decrease. At the same time, the UNHCR has underscored that the death rate has sharply increased: In 2015, one death was reported for every 269 arrivals; in 2016, one death for every 71 arrivals; in 2017, one death for every 55 arrivals; and in 2018, one death for every 51 arrivals. See UNHCR, Desperate Journeys: Refugees and Migrants Arriving in Europe and at Europe's Border January-December 2018 (2019) https://www.unhcr.org/desperatejourneys/. This means that the risk of dying for every migrant who attempts the journey might have increased. Id.

${ }^{125}$ See Cusumano, supra note 7, at 3. See also Last, supra note 118, at 90.

${ }^{126}$ See Legal Action Against Italy Over Its Coordination of Libyan Coast Guard Pull-Backs Resulting in Migrant Deaths and Abuse, Global Legal ACTiOn Network (May 8, 2018), https://www.glanlaw.org/single-post/2018/05/08/Legal-actionagainst-Italy-over-its-coordination-of-Libyan-Coast-Guard-pull-backs-resulting-in-migrant-deaths-and-abuse.
} 
standard is applied, it might be difficult to find an immediate relationship between, for example, the mere provision of equipment to third countries' coast and border guards, and harm possibly inflicted by them in antismuggling operations. It might be the case, however, that this equipment was provided with full awareness that the way that it would be used poses a risk to life. In this way, the knowledge by the EU and the MS gains importance and might offset the remoteness of the factual causation between destination states' conduct and harm. This is in line with the abovementioned interdependence between the elements of knowledge and causation in the context of positive obligations.

Part $\mathrm{C}$ also mentioned that the approach to causation is intertwined with the standard of reasonableness to the effect that if it is relatively easy-and not unreasonable-to undertake alternative protective measures, then the omission to do so could be considered as a relevant cause. Section D.V will further elaborate on the test of reasonableness and the existence of alternatives. The point that this section tries to make is that the arguably uncertain and remote factual causation could be counterbalanced by other legally relevant considerations. ${ }^{127}$

\section{Positive Obligations in the Context of Self-induced Risks}

Besides the involvement of third states, other factors could also reduce the control that the EU and the MS have over the circumstances when life is lost, thus also weakening the causation. In particular, since migrants themselves knowingly engage in life-endangering activities—such as being smuggled in unseaworthy boats - the situations when life is lost are not entirely within the control of countries of destination. Rather, migrants themselves create risks to their lives, which arguably undermines the causation between these countries' conduct and harm.

To address this argument, it is first important to highlight that the ECtHR's case law under Article 2 is clear to the effect that even if an individual creates a risk to that individual's lifesuicide, ${ }^{128}$ or choosing to reside in a dangerous place ${ }^{129}$ - states still have a positive obligation to prevent loss of life. An individual's contribution to the creation of the risk might be a relevant factor in the overall assessment of whether it was reasonable for the state to take protective measures and what measures might be considered reasonable, ${ }^{130}$ but this contribution cannot negate the existence of a positive obligation to prevent loss of life. What is specific about migrants who lose their lives in the context of migration control, however, is that they take risks to defy states' migration control prerogatives. In other words, migrants take risks when engaging in activitieslike unauthorized entries ${ }^{131}$ - that can be considered unlawful. ${ }^{132}$

\footnotetext{
${ }^{127}$ A parallel could be drawn here with the distinction between "factual causation" and "legal causation." While the first one refers to the historical connection between the defendant's negligence and harm, the second one implies a normative inquiry. Jane Stapleton, Cause in Fact and the Scope of Liability for Consequence, 119 L.Q. Rev. 388 (2003); Ken OliphanT \& DonaL NOLAN, TORT LAW 213 (2017).

${ }^{128}$ Keenan v. United Kingdom, App. No. 27229/95, para. 96 (Apr. 3, 2001).

${ }^{129}$ Öneryildiz v. Turkey, App. No. 48939/99, para. 106 (Nov. 30, 2004).

${ }^{130}$ Sarihan v. Turkey, App. No. 55907/08 (2016). The victim died as a result of a mine explosion; he entered a mine field knowing that it was dangerous. There were also warning signs. The ECtHR reasoned that "it is always possible to take more measures to protect people from the dangers presented by a minefield, however it would be impossible to achieve a full level of protection due in particular to the unpredictability of human behavior." The fact that it was possible to take measures that were more protective does not mean that the state has failed to fulfill its positive obligations under Article 2 ECHR, because such more protective measures might be unreasonable. Id.

${ }^{131}$ Saadi v. The United Kingdom, App No. 13229/03, para. 65 (Jan. 29, 2008) (“[U]ntil a State has 'authorised' entry to the country, any entry is 'unauthorised' .... [The ECtHR] does not accept that as soon as an asylum-seeker has surrendered himself to the immigration authorities, he is seeking to effect an 'authorised' entry ....").

${ }^{132}$ For migrants who are granted refugee status, Article 31(1) of the Convention relating to the Status of Refugees, 189 U.N.T.S. 150, is relevant. This provision excepts them from penalties on account of illegal entry or presence. The scope of the provision, however, does not cover the criminalization of illegal entry as such. Gregor Noll, Article 31 (Refugees Unlawfully in the Country of Refugee), in The 1951 Convention ReLATing to the Status OF ReFugEes AND ITS 1967 Protocol: A Commentary 1243 (Andreas Zimmermann ed., 2011).
} 


\section{Positive Obligations in the Context of Unlawful Activities}

The positive obligation to protect life in circumstances when victims have engaged in unlawful activity was discussed in Öneryildiz $v$. Turkey, a case about a gas explosion at a rubbish tip that led to loss of lives. The victims' relatives argued before the ECtHR that Turkey failed to take measures to prevent the loss of life and was therefore in breach of Article 2 of the ECHR. In its defense, Turkey submitted that the affected individuals "knowingly chose to break the law and live in the vicinity of the rubbish tip." ${ }^{33}$ The Court observed that the Turkish authorities-by not applying relevant town-planning regulations_-had a consistent policy that encouraged people to reside in proximity of the dangerous rubbish tip. In other words, the Turkish authorities remained passive in the face of unlawful actions. ${ }^{134}$ This passivity by the state was used in the Court's reasoning to find Turkey in violation of Article 2 of the ECHR.

If the same reasoning is applied to the migration context, it can be said that countries of destination have not remained passive in the face of unlawful actions that breach their immigration legislation. On the contrary, they have made it very clear that they do not tolerate these actions by conducting information and awareness raising campaigns to warn individuals of the dangers associated with human smuggling. ${ }^{135}$

The question then arises of whether destination states should have a positive obligation to prevent loss of life in relation to activities aimed at circumventing legitimate immigration legislation. The answer must be positive because the ECtHR has said that the positive obligation to protect life applies in the context of any activity. This activity must also include illegal acts by the victim. After all, states are under an obligation to ensure the right to life of criminals or suspected criminals in the course of efforts to apprehend them or to prevent their criminal activities. ${ }^{136}$ This analogy should not be understood to the effect that the activities in which migrants engage - such as using the services of human smugglers - are in any way comparable to those of criminals. ${ }^{137}$ The analogy is only utilized here for emphasizing the point that states are under the positive obligation to protect the right to life even when the affected individuals engage in unlawful activities.

An additional distinctive feature of the context - namely engagement in unlawful activities - in which the positive obligation to protect life arises, needs to be highlighted. As was suggested in the introduction to this Article, it is destination states that have left migrants with hardly any choices but to use human smuggling and attempt to enter in an unauthorized manner. In light of the ECtHR's case law, restrictions by the state on the available options for individuals that might enable them to find better ways to ensure their safety are pertinent in the assessment of the positive obligation corresponding to the right to life. ${ }^{138}$ Such obligations will be more demanding when individual choices have been initially limited by the state.

\section{The Test of Reasonableness and the Existence of Alternatives}

In the context of the anti-smuggling measures, such limitations are, however, related to the immigration control interests of destination states. These interests are also a relevant consideration in determining what reasonable measures might be expected to protect the right to life. When the

\footnotetext{
${ }^{133}$ Öneryildiz v. Turkey, App. No. 48939/99, para. 103 (Nov. 30, 2004).

${ }^{134} \mathrm{Id}$. at $104-06$.

${ }^{135}$ EU Action Plan against Migrant Smuggling (2015-2020), at 6, COM (2015) 285 final (May 27, 2015). For questioning the role of these campaigns, see Anne-Line Rodriguez, European Attempts to Govern African Youths by Raising Awareness of the Risks of Migration: Ethnography of an Encounter, 45 J. ETHNIC \& MigRATION STUD. 735 (2019).

${ }^{136}$ McCann and Others v. United Kingdom, 21 Eur. Ct. H.R. 97 (1995).

${ }^{137}$ Article 5 of the UN Smuggling Protocol says that "Migrants shall not become liable to criminal prosecution under this Protocol for the fact of having been the object of conduct set forth in article6 of this Protocol [the conduct of human smuggling]." Protocol against the Smuggling of Migrants by Land, Sea and Air, supplementing the United Nations Convention against Transnational Organized Crime, Jan. 28, 2004, 2241 U.N.T.S. 507.

${ }^{138}$ See, e.g., O’Keeffe v. Ireland, App. No. 35810/09, para. 151 (Jan. 28, 2014).
} 
ECtHR refers to reasonableness in the context of positive obligations, it considers public interestsincluding public policy consideration, budgetary concerns, and the rights of others that possibly might be negatively affected if protection to some individuals is actually extended-as factors that might compete with the interests of the individuals in need of protection. ${ }^{139}$ The interests of states to control the ingress of migrants can be viewed as interests that aim at preserving the citizens' and denizens' rights. ${ }^{140}$

While abandonment of immigration control prerogatives would be unreasonable, there might be alternative measures that cater to states' entitlement to control borders while simultaneously better ensuring migrants' interests to have their lives protected. In other words, there might be reasonable alternatives that are more protective of the migrants than the current anti-smuggling measures, and that are simultaneously sensitive to the destination states' interests. The test of reasonableness implies searching for such alternatives. Put differently, the reasonableness of the current measures that are characterized with containment in third countries cannot be assessed without consideration of possible alternatives. At this stage the analysis can bifurcate into two directions: procedural and substantive.

\section{Procedural Positive Obligations}

The procedural approach entails examining whether the EU and the MS have considered alternative measures for protecting migrants' lives. The test of reasonableness implies that they must assess alternative measures and the prospects that each measure holds. Support for this approach can be found in Budayeva and Others v. Russia, where the ECtHR observed that the state is expected to come forward and assert whether it had envisioned "other solutions to ensure the safety" of the population. ${ }^{141}$ Similarly, in Kolyadenko and Others $v$. Russia, the respondent state was expected to explain how any protective measures that were undertaken were relevant and efficient in alleviating the harm sustained by the applicant. ${ }^{142}$ It follows that states are expected to identify different protective measures and assess their effectiveness. If they have failed to take this procedural step - the identification and assessment of alternatives - it is more likely that the measures actually undertaken might be considered inadequate. ${ }^{143}$ In the context of migrants' deaths, this means that the EU and the MS have to show that alternatives to containmentfor example, legal routes through the provision of humanitarian visas-have been taken into regard and their effectiveness to save lives and alleviate immigration control concerns assessed. ${ }^{144}$

The assessment of alternative measures might be hampered by epistemic uncertainty, in that it might not be possible to empirically prove-for example, with reference to concrete data and scientific studies - the effectiveness of different measures and demonstrate which protective measures might be more effective. This difficulty was mentioned above in the context of migrants'

\footnotetext{
${ }^{139}$ Stoyanova, supra note 92.

${ }^{140}$ The effectiveness of states to guarantee rights presupposes the idea of a bounded community. GREGOR NOLL, Negotiating Asylum: The EU Acquis, Extraterritorial Protection and the Common Market of Deflection 489-90 (2000).

${ }^{141}$ Budayeva and Others v. Russia, App. Nos. 15339, 21166/02, 20058/02, 11673/02 \& 15343/0, para. 156 (Mar. 20, 2008). Such "other solutions" were proposed by the applicants—-defense and warning infrastructure regarding mudslides. Id.

${ }^{142}$ Kolyadenko and Others v. Russia, App No. 17423/05, para. 167 (Feb. 28, 2012).

${ }^{143}$ For an outline of the development of procedural positive obligations, see Eva Brems, Procedural Protection: An Examination of Procedural Safeguards Read into Substantive Convention Rights, in SHAPING RIGHTS IN THE ECHR: THE Role of the European Court of Human Rights in Determining the Scope of Human Rights 137 (Eva Brems \& Janneke Gerards eds., 2013); Eva Brems, The "Logics" of Procedural-Type Review by the European Court of Human Rights, in Procedural Review in European Fundamental Rights Cases 17 (Eva Brems \& Janneke Gerards eds., 2017).

${ }^{144}$ Any alternative measures for protecting life have to be equally effective in preserving states' interests. See Vladislava Stoyanova, The Disjunctive Structure of Positive Rights under the European Convention on Human Rights, 87 NoRDIC J. INT'L L. 344, 356 (2018).
} 
deaths. It is a difficulty that has also more generally emerged in positive obligations cases considered by the ECtHR. In this relation, the ECtHR has stated that:

Except in cases of manifest arbitrariness and error, it is not its function to call into question the findings of fact made by the domestic authorities. This is particularly true in relation to scientific expert assessments, which by definition call for specific and detailed knowledge of the subject. ${ }^{145}$

The problem of epistemic uncertainty, however, cannot result in a blind belief that the measures undertaken by the state are effective and sufficient. Although the Court might not be in a position to assess alternatives due to scientific and epistemic uncertainties, it can still assess whether-in the process of decision-making at national level—alternatives have been considered based on existing scientific studies. ${ }^{146}$ In addition, the procedural approach to positive obligations might imply that states have to undertake studies and collect data that can contribute to better decisionmaking. When this approach is applied to the migration context, it means that for the EU and the MS to comply with their positive obligation to ensure the right to life, they need to initiate studies to assess the effectiveness of their current policies and to investigate whether other measures might offer reasonable alternatives to the current policies. ${ }^{147}$

An additional nuance to the procedural positive obligation can be added here. In particular, the more serious the harm the affected individuals suffer, the more empirical information the EU and the MS will need to submit showing that the extension of alternative forms of protection will be too burdensome for general interests (i.e. states' immigration control interests). ${ }^{148}$ This implies an expectation that they submit well-grounded empirical data communicating that alternatives - such as legal channels through humanitarian visas-will seriously impact states' migration control interests by, for example, leading to more migrants entering the EU than under the current regime. In addition, the empirical evidence substantiating an argument that a particular means of protection is ineffective, unreasonable, or too burdensome will need to be more reliable.

When these principles are applied to the loss of life in the context of migration control, the following emerges: The individuals are very severely affected, in that they risk losing their lives. Thus, the EU and the MS have to present much more reliable evidence than that which is currently available regarding the effectiveness of the current measures of departure prevention and containment for ensuring the right to life. States will also have to present more reliable information than is currently available on any alternative measures that will be too burdensome or unreasonable.

\section{Substantive Positive Obligations}

The procedural positive obligation corresponding to the right to life that demands assessment of alternatives and undertaking of studies does not imply that the EU and the MS are in fact under an

\footnotetext{
${ }^{145}$ Fernandes v. Portugal, App. No. 56080/13, para. 109 (Dec. 19, 2017).

${ }^{146}$ See, for example, the approach in Wenner v. Germany, App. No. 62303/13, para. 58, 62 (Sept. 1, 2016).

${ }^{147}$ For reflections on the pitfalls and limitations of statistics regrading migrants' deaths in the context of migration control and suggestions as to what kind of data might needed to be collected in the future, see Kate Dearden et al., Mortality and Border Deaths Data: Key Challenges and Ways Forward, in Border DeATHS: CAUSES, DyNAMICS AND CONSEQUENCES OF Migration-Related Mortality 53 (Paolo Cuttitta \& Tamara Last eds., 2019). For a call for better data, see Hubb Dijstelbloem et al., Moving Forward: Between Utopian and Dystopian Visions of Migration Politics, in BORDER DeATHS: Causes, Dynamics and Consequences of Migration-related Mortality 149 (Paolo Cuttitta \& Tamara Last eds., 2019).

${ }^{148}$ Robert Alexy, The Wight Formula for Weighing and Balancing, in STUdies IN THE Philosophy of LAW: FronTIERS OF THE ECONOMIC ANALYsis of LAW 25 (Jerzy Stelmach et al. eds., 2007); Julian Rivers, Proportionality and Variable Intensity of Review, 36 CAmbridge L.J. 174, 205 (2006). See also Jonas Christoffersen, Fair BalanCe: Proportionality, Subsidiarity and Primarity in the European Convention on Human Rights 191 (2009).
} 
obligation to apply alternative measures. Such a demand could be raised if a substantive analysis were undertaken as to the different types of alternative measures and their reasonableness. Admittedly, such an analysis is difficult if the abovementioned procedural positive obligation remains unperformed, which reveals the interconnectedness of the two obligations.

Nonetheless, it is useful to exemplify how a substantive analysis could be performed with reference to humanitarian visas as a possible alternative to the anti-smuggling measures. This analysis needs to be approached with the caveat that positive obligations in human rights law are generally elusive and their precise scope can only be assessed in casu. Therefore, it would be impossible to indicate an exhaustive list of such obligations, and-as has been systematically observed by the $\mathrm{ECtHR}^{149}$ — states have at their disposal different means to ensure the right to life, and the choices as to the means fall within states' discretion. ${ }^{150}$ The analysis below therefore is meant to be only illustrative.

To perform this analysis, a more concrete identification of the competing interests is necessary. If the interest of the EU and the MS is not to receive any migrants at all-including asylum-seekers whose claims need to be assessed-then the above-mentioned alternative of humanitarian visas does not further this interest. This interest would preclude humanitarian visas as a relevant alternative measure. The EU policy documents, however, do not refer to such an interest and, in any case, under the current measures, asylum-seekers still reach the EU territory despite the anti-smuggling methods and containment-through the so called "spontaneous" arrivals.

If the interest is rather to prevent irregular entries and "spontaneous" arrivals, then humanitarian visas in fact advance this interest and can also ensure the safety of the potential recipients. At the same time, the suggested alternative might lead to a similar number of individuals whose asylum claims have to be eventually assessed by the MS. It might thus not be more expensive from the perspective of the EU's and the MS's interests. ${ }^{151}$

The problem with the current anti-smuggling measures is that they do not differentiate between persons in need of protection and other categories of migrants. Therefore, asylum-seekers might be left with no other reasonable options_-including protection alternatives - but to risk their lives to seek protection. ${ }^{152}$ As suggested in Section D.I above, the causation between the EU and the MS conduct and the risk to life might be feeble. Nevertheless, the right to seek asy$\operatorname{lum}^{153}$ and the EU and the MS general allegiance to the international protection system can be normative considerations that influence the approach to causation in this context. As already suggested above, the establishment of causal links between omissions and harm in the context of positive obligations can be shaped by certain values. In addition, the severity of the harm-risking one's life or returning to a country where there is a risk of persecution-and the likelihood of its materialization might be too sufficiently high to suggest convincingly that alternatives, such as humanitarian visas, are not unreasonable.

\footnotetext{
${ }^{149}$ See Stoyanova, supra note 144 . The ECtHR has consistently observed that "where the State is required to take positive measures, the choice of means is in principle a matter that falls within the Contracting State's margin of appreciation." Budayeva and Others v. Russia, App. Nos. 15339, 21166/02, 20058/02, 11673/02 \& 15343/0, para. 134 (Mar. 20, 2008); Öneryildiz v. Turkey, App. No. 48939/99, para. 107 (Nov. 30, 2004); Kolaydenko and Others v. Russia, App. No. 17423/ 05, para. 160 (Feb. 28, 2012); Cevrioglu v. Turkey, App. No. 69546/12, para. 55 (Oct. 4, 2016); Fadeyeva v. Russia, App. No. 55723/00, para. 96 (June 9, 2005).

${ }^{150}$ In relation to the EU, the choice of means is limited by the scope of the EU competence. See Section B.II above.

${ }^{151}$ For a more detailed assessment of the economic and budgetary costs under the current regime where the issuance of humanitarian visa is not an option under EU law, see Eur. Parl., Draft Report with Recommendation to the Commission on Humanitarian Visas (2018/2271(INL)), at 7 (Nov. 26, 2018); Eur. Parl., Humanitarian Visas: European Added Value Assessment Accompanying the European Parliament's Legislative Own-Initiative Report, EUROPEAN PARLIAMENT RESEARCH SERVICE (2018), https://op.europa.eu/en/publication-detail/-/publication/a3b57ef6-d66d-11e8-9424-01aa75ed71a1/ language-en/format-PDF.

${ }^{152}$ This was precisely the situation depicted in the Opinion of Advocate General Mengozzi at para. 157, 173, Case C-638/16 PPU, X \& X v. Belgium (Feb. 7, 2017).

${ }^{153} \mathrm{EU}$ Charter art. 18.
} 
The analysis would be incomplete without recognizing the gamut of legal and practical problems raised by the issuing of humanitarian visas. ${ }^{154}$ These problems need to be included in the assessment of the reasonableness of this alternative. It might be that the current measures need only be supplemented with alternatives, such humanitarian visas, to be considered compatible with the positive obligation of ensuring the right to life. This might mean that the EU and the MS need not abandon the anti-smuggling measures aiming at containment, but simply complement them with other measures.

At this point, we are faced with the impreciseness of positive obligations in human rights law. In contrast to the obligation upon the state to ensure-for example, that its police officers do not shoot persons unless "absolutely necessary" and only in strictly defined circumstances ${ }^{155}$ —any positive obligations to ensure the right to life are more vague. The weakness of the positive obligation to provide for humanitarian visas must therefore be acknowledged. Despite their frailness, positive obligations corresponding to the right to life still compel the EU and the MS to be attentive about the cumulative outcome of their migration policies. The more successful the EU and the MS are in their containment policies, and the more unlikely any protection possibilities in the region of containment are, the more likely it is that the positive obligation to protect life has remained unfulfilled. As destination states' control over different factors determining the success of a migration attempt solidifies, the causal chain linking denials of humanitarian visas and harm becomes tighter. In some specific factual circumstances, it might even be possible to concretize these obligations to the effect that the granting of a humanitarian visa might be the sole avenue to avoid death, or risk to life and persecution, or other serious forms of ill-treatment.

\section{E. Conclusion}

According to the EU policy documents, "[s]aving lives of people in distress is a primary goal of EU action in relation to managing the EU external borders." 156 The chosen means for achieving this objective is taking measures against human smuggling by containing migrants in third countries via a cooperative framework with the latter whereby they are provided with various forms of support to prevent migrants' departure. This Article has examined whether the chosen means for combating human smuggling comply with the positive obligations corresponding to the right to life under Article 2 of the EU Charter.

This examination has shown that the fact that the migrants affected by the measures are located outside the EU territory might not prevent the triggering of the Charter. It was also clarified that the Charter can be invoked against the EU institutions and bodies even when they act outside the EU legal framework. This is important because many of the antismuggling measures are based on informal arrangements with third states. I have also suggested that because there is specific EU law in the area of human smuggling, it might be possible to argue that the Charter is also activated in relation to the MS.

A substantial part of this Article addressed the question of how the right to life under the Charter might generate positive obligations. In principle, positive obligations under the Charter raise many issues that are yet to be resolved, including their application in extraterritorial circumstances. This will be an object of future judicial developments. Still, I offered possible lines of argumentation with reference to the standards developed in the ECtHR's case law. A finding that the EU or the MS have failed to fulfill their positive obligations requires taking into account their

\footnotetext{
${ }^{154}$ For a detailed discussion, see Gregor Noll et al., Study of the Feasibility of Processing Asylum Claims Outside the EU against the Background of the Common European Asylum System and the Goal of a Common Asylum Procedure, DANISH CTR. HUM. RTS. (2002).

${ }^{155}$ See EU Charter arts. 2, 52; European Convention on Human Rights art. 2(2).

${ }^{156}$ Progress Report on the Implementation of the European Agenda on Migration, at, 11-12 COM (2019) 126 final (Mar. 6, 2019).
} 
knowledge about the risk to life, the causation between such risks, the EU's and the MS's conduct, and the reasonableness of the antismuggling measures in light of possible alternative measures. As I have shown, the existence of alternatives - such as humanitarian visas - and the assessment of their reasonableness are crucial for any finding that positive obligations remain unfulfilled.

But what follows if a determination of non-fulfillment is ultimately made? States enjoy discretion as to how they comply with positive obligations, which makes these obligations lacking in precision. Although not impossible, it is difficult to make the argument that a concrete measure-such as granting of a humanitarian visa - is the positive obligation that corresponds to migrants' right to life. My conclusions are accordingly more of a relational nature and an expression of spectrums. The stronger certain factors are-such as the pool of contained migrants that includes asylum-seekers with reasonable protection claims, the availability of few possibilities for protection in the region of containment, and highly effective measures of containment-the tighter the causal link between destination states' conduct and harm and the easier it is to find a failure on their part. 